Article

\title{
Expression of Adenosine Receptors in Rodent Pancreas
}

\author{
Mikio Hayashi (D) \\ Department of Cell Physiology, Institute of Biomedical Science, Kansai Medical University, 2-5-1 shin-machi, \\ Hirakata, Osaka 573-1010, Japan; hayashmi@hirakata.kmu.ac.jp; Tel.: +81-72-804-2322
}

Received: 17 September 2019; Accepted: 24 October 2019; Published: 25 October 2019

\begin{abstract}
Adenosine regulates exocrine and endocrine secretions in the pancreas. Adenosine is considered to play a role in acini-to-duct signaling in the exocrine pancreas. To identify the molecular basis of functional adenosine receptors in the exocrine pancreas, immunohistochemical analysis was performed in the rat, mouse, and guinea pig pancreas, and the secretory rate and concentration of $\mathrm{HCO}_{3}{ }^{-}$in pancreatic juice from the rat pancreas were measured. The $\mathrm{A}_{2 \mathrm{~A}}$ adenosine receptor colocalized with ezrin, an A-kinase anchoring protein, in the luminal membrane of duct cells in the mouse and guinea pig pancreas. However, a strong signal ascribed to $A_{2 B}$ adenosine receptors was detected in insulin-positive $\beta$ cells in islets of Langerhans. The $A_{2 A}$ adenosine receptor agonist 4-[2-[[6-Amino-9-( $N$-ethyl- $\beta$-D-ribofuranuronamidosyl)-9H-purin-2-yl]amino]ethyl]benzenepropanoic acid (CGS 21680) stimulated $\mathrm{HCO}_{3}{ }^{-}$-rich fluid secretion from the rat pancreas. These results indicate that $\mathrm{A}_{2 \mathrm{~A}}$ adenosine receptors may be, at least in part, involved in the exocrine secretion of pancreatic duct cells via acini-to-duct signaling. The adenosine receptors may be a potential therapeutic target for cancer as well as exocrine dysfunctions of the pancreas.
\end{abstract}

Keywords: adenosine receptor; duct; ezrin; pancreas; secretion

\section{Introduction}

The pancreas performs both exocrine and endocrine functions. Pancreatic acini secrete digestive enzyme- and $\mathrm{Cl}^{-}$-rich neutral fluid, and ducts secrete an $\mathrm{HCO}_{3}{ }^{-}$-rich pancreatic juice that neutralizes acidic chyme in the duodenum. The generally accepted model for $\mathrm{HCO}_{3}{ }^{-}$transport involves electrogenic $\mathrm{Cl}^{-}-\mathrm{HCO}_{3}{ }^{-}$exchangers (SLC26A) that operate in parallel with cAMP-activated $\mathrm{Cl}^{-}$ channels [cystic fibrosis transmembrane conductance regulator (CFTR)] and $\mathrm{Ca}^{2+}$-activated $\mathrm{Cl}^{-}$ channels (ANO1/TMEM16A) on the luminal membranes of duct cells [1-4]. Islets of Langerhans are involved in maintaining glucose homeostasis and comprise $\alpha_{-}, \beta_{-}, \gamma_{-}, \delta_{-}$, and $\varepsilon$-cells, which secrete glucagon, insulin and amylin, pancreatic polypeptide, somatostatin, and ghrelin, respectively [5].

Both exocrine and endocrine cells are regulated by nucleotides, as well as parasympathetic and sympathetic nerves and hormones [6]. Previous studies by Novak and coworkers demonstrated that the purinergic system has a coordinating function in acini-to-duct signaling [6]. Cholecystokinin stimulates the release of ATP, ectonucleoside triphosphate diphosphohydrolase (CD39), and ecto-5' -nucleotidase (CD73) from acini into pancreatic juice [7]. The ectonucleosides hydrolyze ATP to adenosine in the ductal lumen. Adenosine activates $\mathrm{Cl}^{-}$conductance in pancreatic duct cells of the rat and guinea pig $[8,9]$. A pharmacological study indicated that $\mathrm{A}_{2 \mathrm{~A}}$ adenosine receptors were involved in the water and $\mathrm{HCO}_{3}{ }^{-}$ secretory response in the dog pancreas [10]. In endocrine cells, $\mathrm{N}^{6}$-L-phenyl-isopropyl-adenosine, an $\mathrm{A}_{1}$ adenosine receptor agonist, reduced glucose-induced insulin secretion from the perfused rat and mouse pancreas [11-13]. In contrast, adenosine at $100 \mu \mathrm{M}$ augmented insulin secretion through the $\mathrm{A}_{2 \mathrm{~A}}$ adenosine receptor on isolated mouse islets [14].

$A_{1}, A_{2 A}, A_{2 B}$, and $A_{3}$ adenosine receptors are expressed in the rat and mouse pancreas $[8,14,15]$. Real-time PCR revealed that the rank order of the adenosine mRNA level was $A_{2 A}>A_{2 B} \geq$ 
$A_{3}>A_{1}$, where the level of $A_{2 A}$ was at least five times higher than of other receptors in the rat pancreas [8]. Immunohistochemical studies showed that $A_{2 A}$ and $A_{2 B}$ adenosine receptors were localized in the luminal membranes of rat duct cells and human duct cell lines [8,9]. Additionally, $\mathrm{A}_{2 \mathrm{~A}}$ adenosine receptors were detected in the rat islets, most likely in $\beta$ cells [8]. $\mathrm{A}_{1}$ and $\mathrm{A}_{2 \mathrm{~A}}$ adenosine receptors were also found in isolated $\alpha$-cells from mouse islets, and 4-[2-[[6-Amino-9-(N-ethyl- $\beta$-D-ribofuranuronamidosyl)-9H-purin-2-yl]amino]ethyl]benzenepropanoic acid (CGS 21680), an $\mathrm{A}_{2 \mathrm{~A}}$ adenosine receptor agonist, stimulated glucagon secretion [16]. Protein expression of $A_{1}$ adenosine receptors was identified in $\alpha$-cells from the human pancreas [17]. However, the expression and function of adenosine receptors in primary human pancreatic duct cells are unknown.

$A_{2 A}$ and $A_{2 B}$ adenosine receptors generally increase cAMP levels, whereas $A_{1}$ and $A_{3}$ receptors decrease them [18]. Thus, the present study focused on functional $A_{2 A}$ and $A_{2 B}$ adenosine receptors involved in the ductal secretion of the pancreas. The results reveal that mouse and guinea pig duct cells express $A_{2 A}$ adenosine receptors. However, $\beta$ cells in the islets express both $A_{2 A}$ and $A_{2 B}$ adenosine receptors. Furthermore, it was demonstrated that $A_{2 A}$ adenosine receptors contribute to exocrine secretion in the rat pancreas.

\section{Results}

\section{1. $A_{2 A}$ and $A_{2 B}$ Receptors Expressed in Pancreatic Islets of the Rat}

A previous study showed that $\mathrm{A}_{2 \mathrm{~A}}$ adenosine receptors were expressed in the islets of the rat pancreas [8]. In order to determine the cells that expressed $A_{2 A}$ and $A_{2 B}$ adenosine receptors, triple staining of adenosine receptors was performed with insulin and glucagon on paraffin sections of the rat pancreas. The immunofluorescence of $\mathrm{A}_{2 \mathrm{~A}}$ adenosine receptors was detected in insulin-positive $\beta$ cells [19] (Figure 1A-C), but in few glucagon-positive $\alpha$-cells (Figure 1D). Additionally, a strong signal ascribed to $A_{2 B}$ adenosine receptors was detected specifically in insulin-positive $\beta$ cells (Figure 1E-H). Immunofluorescence was diminished with normal rabbit IgG for the isotype control (Figure 1I-L).
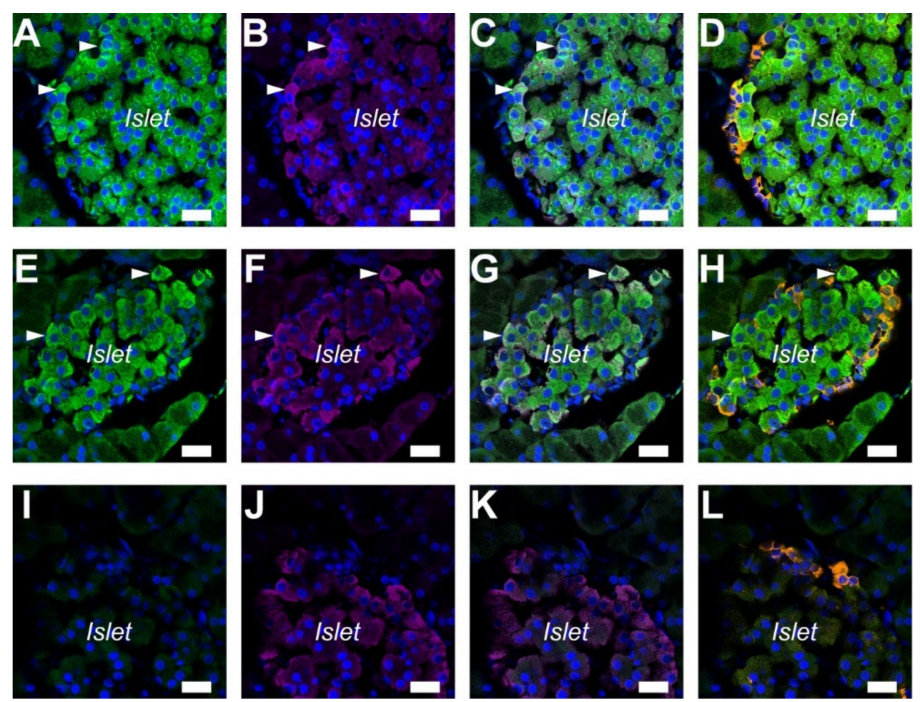

Figure 1. Immunolocalization of $\mathrm{A}_{2 \mathrm{~A}}$ and $\mathrm{A}_{2 \mathrm{~B}}$ adenosine receptors in the pancreatic islets of the rat. (A) Fluorescence of $\mathrm{A}_{2 \mathrm{~A}}$ adenosine receptor in the cell membrane (arrowheads). (B) Fluorescence image of insulin. (C) Overlay image of $\mathbf{A}$ and $\mathbf{B}$. (D) Overlay of $\mathbf{A}$ and fluorescence image of glucagon (orange) in the same sample. (E) Fluorescence of $A_{2 B}$ adenosine receptor in cells (arrowheads). (F) Fluorescence image of insulin. (G) Overlay image of $\mathbf{E}$ and $\mathbf{F}$. (H) Overlay of $\mathbf{E}$ and fluorescence image of glucagon (orange). (I) Isotype control image of the rat pancreas with normal rabbit IgG $(2 \mu \mathrm{g} / \mathrm{mL})$. (J) Fluorescence image of insulin. (K) Overlay image of $\mathbf{I}$ and $\mathbf{J}$. (L) Overlay of $\mathbf{I}$ and fluorescence image of glucagon (orange). 4',6-diamidino-2-phenylindole (DAPI) was used to stain nuclei (blue). Representative images of three rats are shown. Bars $=20 \mu \mathrm{m}$. 


\section{2. $A_{2 A}$ and $A_{2 B}$ Receptors Expressed in Pancreatic Islets of the Mouse}

The immunolocalization of the $\mathrm{A}_{2 \mathrm{~A}}$ and $\mathrm{A}_{2 \mathrm{~B}}$ adenosine receptors was examined with paraffin sections of the mouse pancreas. Immunofluorescence ascribed to the $A_{2 A}$ adenosine receptors was localized on the inside of cells (Figure 2A). The $A_{2 A}$ adenosine receptors were expressed in insulin-positive $\beta$ cells and glucagon-positive $\alpha$-cells (Figure 2B-D). However, a strong signal ascribed to $A_{2 B}$ adenosine receptors was detected specifically in insulin-positive $\beta$ cells (Figure 2E-H). The results were consistent with the distribution of $A_{2 B}$ adenosine receptors in the rat pancreas. Immunofluorescence was diminished with normal rabbit IgG for the isotype control (Figure 2I-L).
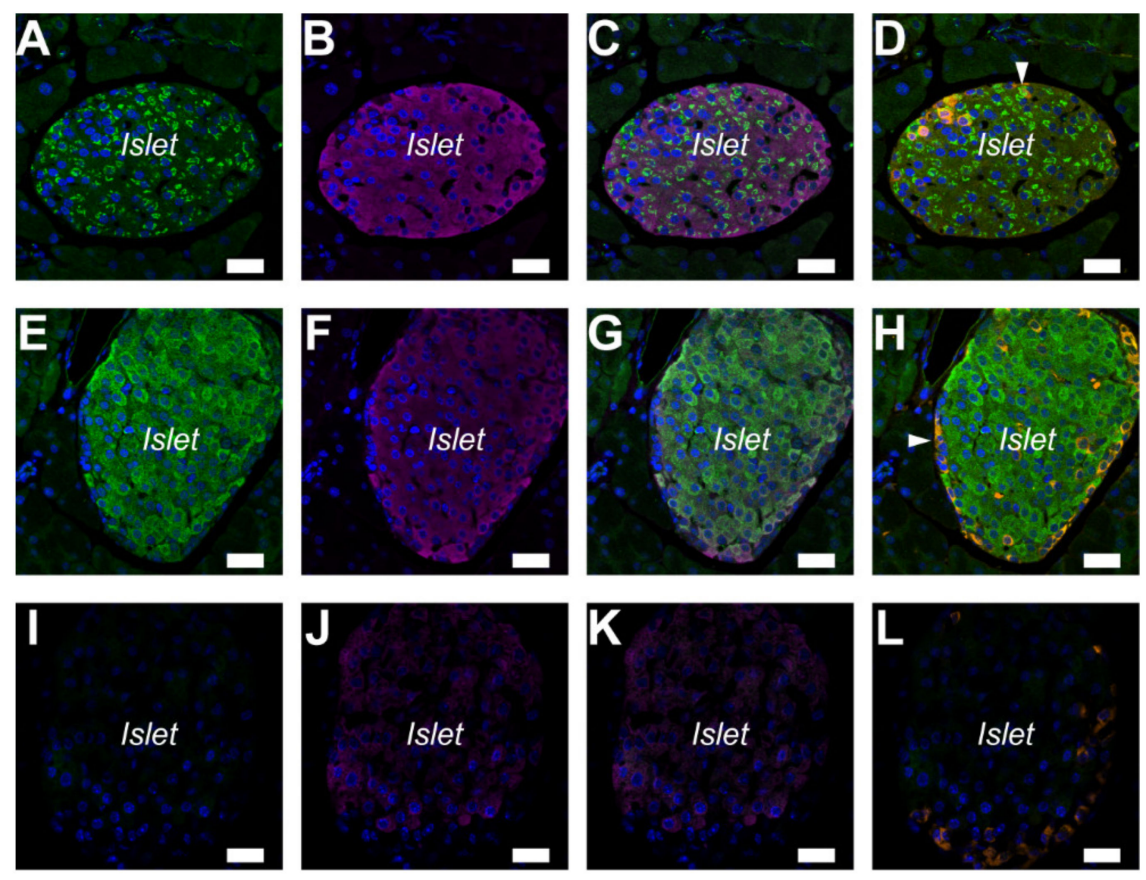

Figure 2. Immunolocalization of $\mathrm{A}_{2 \mathrm{~A}}$ and $\mathrm{A}_{2 \mathrm{~B}}$ adenosine receptors in pancreatic islets of the mouse. (A) Fluorescence of $\mathrm{A}_{2 \mathrm{~A}}$ adenosine receptor inside cells. (B) Fluorescence image of insulin. (C) Overlay image of A and B. (D) Overlay of A and fluorescence image of glucagon (orange) in the same sample. A few glucagon-positive $\alpha$-cells expressed $\mathrm{A}_{2 \mathrm{~A}}$ adenosine receptors (arrowhead). (E) Fluorescence of $\mathrm{A}_{2 \mathrm{~B}}$ adenosine receptor in cells. (F) Fluorescence image of insulin. (G) Overlay image of $\mathbf{E}$ and $\mathbf{F}$. (H) Overlay of $\mathbf{E}$ and fluorescence image of glucagon (orange). Glucagon-positive $\alpha$-cells did not express $\mathrm{A}_{2 \mathrm{~B}}$ adenosine receptors (arrowhead). (I) Isotype control image of the mouse pancreas with normal rabbit IgG $(2 \mu \mathrm{g} / \mathrm{mL})$. (J) Fluorescence image of insulin. (K) Overlay image of I and J. (L) Overlay of I and fluorescence image of glucagon (orange). DAPI was used to stain nuclei (blue). Representative images of three mice are shown. Bars $=20 \mu \mathrm{m}$.

\section{3. $A_{2 A}$ Receptors Expressed in the Pancreatic Ducts of Mice}

Our previous study showed that both $\mathrm{A}_{2 \mathrm{~A}}$ and $\mathrm{A}_{2 \mathrm{~B}}$ adenosine receptors localized in the luminal membranes of rat duct cells [9]. In order to distinguish between pancreatic ducts and blood vessels, triple staining of adenosine receptors was performed with ezrin and PECAM-1 (platelet endothelial cell adhesion molecule-1) on paraffin sections of the mouse pancreas, as reported previously in the rat and guinea pig $[4,9]$. Immunofluorescence ascribed to the $A_{2 A}$ adenosine receptor was colocalized with ezrin, an A-kinase anchoring protein, to the luminal membrane of the pancreatic duct (Figure 3A-C). However, immunofluorescence ascribed to the $A_{2 B}$ adenosine receptor was weak in mouse ducts (Figure $3 E-G$ ). Additionally, the signal for $A_{2 A}$ and $A_{2 B}$ adenosine receptors was detected in PECAM-1-positive endothelial cells of blood vessels (Figure 3D,H). Immunofluorescence was diminished with normal rabbit IgG for the isotype control (Figure 3I-L). 

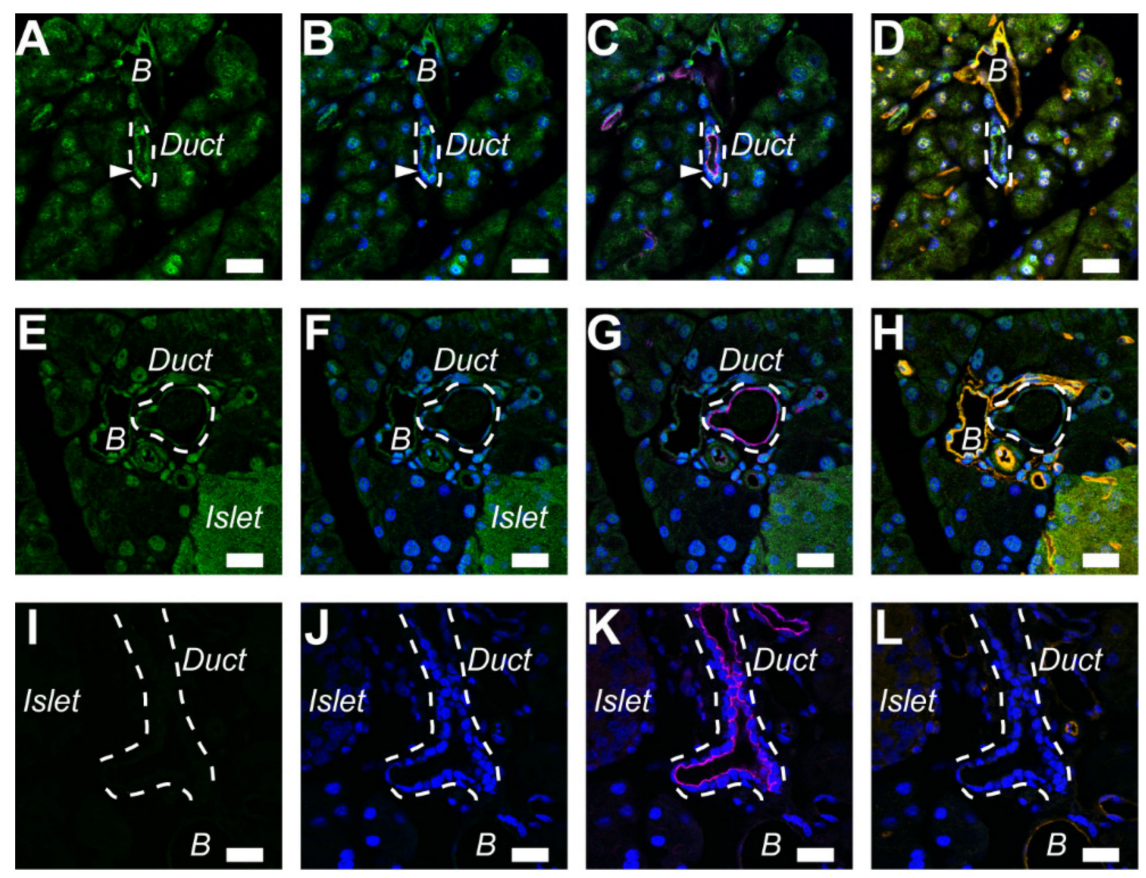

Figure 3. Immunolocalization of $\mathrm{A}_{2 \mathrm{~A}}$ adenosine receptors in the pancreatic duct of the mouse. (A) Fluorescence of $\mathrm{A}_{2 \mathrm{~A}}$ adenosine receptor in the luminal membrane of duct cells (arrowhead). The broken lines indicate a duct. The signal was detected in the endothelial cells of blood vessels (B). (B) Overlay of A and nuclear staining with DAPI (blue). (C) Overlay of B and fluorescence image of ezrin (purple). (D) Overlay of $\mathbf{B}$ and fluorescence image of a blood vessel marker (orange: platelet endothelial cell adhesion molecule-1, or PECAM-1) in the same sample. (E) The signal for the $\mathrm{A}_{2 \mathrm{~B}}$ adenosine receptor was detected in the blood vessels (B) and islet. The broken line indicates a duct. (F) Overlay of E and nuclear staining. (G) Overlay of F and fluorescence image of ezrin (purple). (H) Overlay of $\mathbf{F}$ and fluorescence image of PECAM-1 (orange). (I) Isotype control image of the mouse pancreas with normal rabbit IgG $(2 \mu \mathrm{g} / \mathrm{mL})$. (J) Overlay of I and nuclear staining. (K) Overlay of $\mathbf{J}$ and fluorescence image of ezrin (purple). (L) Overlay of $\mathbf{J}$ and fluorescence image of PECAM-1 (orange).

Representative images of three mice are shown. Bars $=20 \mu \mathrm{m}$.

\section{4. $A_{2 A}$ Receptors Expressed in the Pancreatic Ducts of Guinea Pigs}

We performed immunostaining of $\mathrm{A}_{2 \mathrm{~A}}$ and $\mathrm{A}_{2 \mathrm{~B}}$ adenosine receptors with ezrin and PECAM-1 on paraffin sections of the guinea pig. Immunofluorescence ascribed to the $A_{2 A}$ adenosine receptor was colocalized with ezrin to the luminal membrane of the pancreatic duct (Figure $4 \mathrm{~A}-\mathrm{C}$ ). However, immunofluorescence ascribed to the $A_{2 B}$ adenosine receptor was weak in guinea pig ducts (Figure $4 \mathrm{E}-\mathrm{G}$ ). The signal for $\mathrm{A}_{2 \mathrm{~B}}$ adenosine receptors was detected in the PECAM-1-positive endothelial cells of blood vessels (Figure $4 \mathrm{H}$ ). Immunofluorescence was diminished with normal rabbit IgG for the isotype control (Figure 4I-L). 

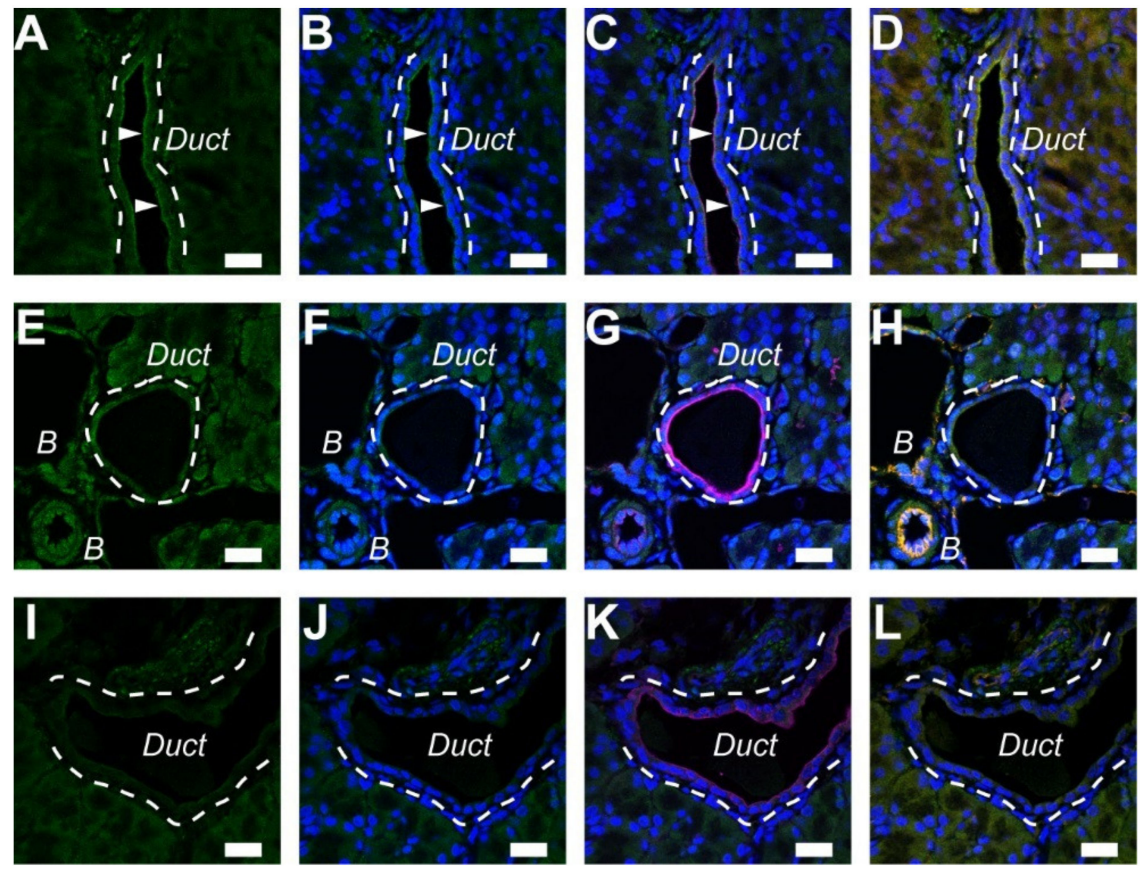

Figure 4. Immunolocalization of $\mathrm{A}_{2 \mathrm{~A}}$ adenosine receptors in the pancreatic duct of the guinea pig. (A) Fluorescence of the $\mathrm{A}_{2 \mathrm{~A}}$ adenosine receptor in the luminal membrane of duct cells (arrowheads). The broken lines indicate a duct. (B) Overlay of A and nuclear staining with DAPI (blue). (C) Overlay of $\mathbf{B}$ and fluorescence image of ezrin (purple). (D) Overlay of $\mathbf{B}$ and fluorescence image of a blood vessel marker (orange: PECAM-1) in the same sample. (E) The signal for the $A_{2 B}$ adenosine receptor was detected in the blood vessels (B). The broken line indicates a duct. (F) Overlay of $\mathbf{E}$ and nuclear staining. (G) Overlay of $\mathbf{F}$ and fluorescence image of ezrin (purple). (H) Overlay of $\mathbf{F}$ and fluorescence image of PECAM-1 (orange). (I) Isotype control image of the guinea pig pancreas with normal rabbit IgG $(2 \mu \mathrm{g} / \mathrm{mL})$. (J) Overlay of $\mathbf{I}$ and nuclear staining. (K) Overlay of $\mathbf{J}$ and fluorescence image of ezrin (purple). (L) Overlay of $\mathbf{J}$ and fluorescence image of PECAM-1 (orange). Representative images of three guinea pigs are shown. Bars $=20 \mu \mathrm{m}$.

\subsection{Expression of $A_{2 A}$ and $A_{2 B}$ Receptor Protein in Rat Pancreatic Ducts}

We next performed Western blot analysis to examine the expression of $A_{2 A}$ and $A_{2 B}$ adenosine receptors in the rat pancreatic ducts. We detected $\mathrm{A}_{2 \mathrm{~A}}$ (ADORA2A, $54 \mathrm{kDa}$ ) and $\mathrm{A}_{2 \mathrm{~B}}$ (ADORA2B, $55 \mathrm{kDa}$ ) adenosine receptors in the lysates of the isolated ducts (Figure $5 ; n=2$ rats). In addition, the $A_{2 A}$ and $A_{2 B}$ adenosine receptors were detected in the lysates of Capan-1, which is a human pancreas adenocarcinoma cell line, but not in HEK293 cells $(n=2)$.

A

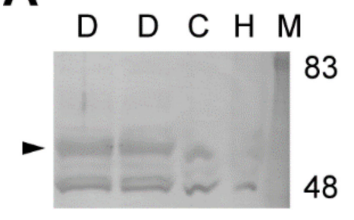

B

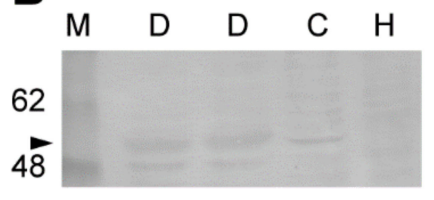

Figure 5. Immunoblot of $A_{2 A}(A)$ and $A_{2 B}(B)$ adenosine receptors from the rat pancreatic duct. Protein samples were resolved by SDS-PAGE. Arrowheads indicate adenosine receptor proteins detected by immunoblotting using anti-ADORA2A (A, 1:200, sc-13937) or anti-ADORA2B (B, 1:1000, AAR-003) antibody. Representative membranes from two independent experiments are shown. M, marker; D, duct; C, Capan-1; H, HEK293. 


\section{6. $A_{2 A}$ Receptor Agonist Elicited Pancreatic Secretion in Rats}

In order to demonstrate whether adenosine regulated exocrine secretion, the secretory rate and concentration of protein and $\mathrm{HCO}_{3}{ }^{-}$in pancreatic juice from the rat pancreas were measured. Specific adenosine receptor agonists were tested to identify functional adenosine receptors. The intravenous injection of CGS 21680 (20 nmol/kg body weight), an $A_{2 A}$ adenosine receptor agonist, significantly increased the secretory rate from $0.40 \pm 0.05$ in the control to $0.72 \pm 0.09 \mu \mathrm{L} / \mathrm{min}$ after $20 \mathrm{~min}$ and sustained it for $20 \mathrm{~min}$ (Figure $6 \mathrm{~A} ; n=6 \mathrm{rats}$ ). The concentration of protein in pancreatic juice was decreased from $77.7 \pm 8.4$ to $41.2 \pm 5.5 \mathrm{~g} / \mathrm{L}$ after $40 \mathrm{~min}$, indicating ductal secretion (Figure 6B). In addition, the $\mathrm{HCO}_{3}{ }^{-}$concentration was increased from $38.2 \pm 3.1$ to $52.7 \pm 5.6 \mathrm{mM}$ after $40 \mathrm{~min}$, indicating $\mathrm{HCO}_{3}{ }^{-}$-rich ductal secretion (Figure $6 \mathrm{C}$ ). In contrast, 2-(\{6-Amino-3,5-dicyano-4-[4-(cyclopropylmethoxy)phenyl]pyridin-2-yl\}sulfanyl)acetamide (BAY 60-6583, $20 \mathrm{nmol} / \mathrm{kg}$ body weight), an $\mathrm{A}_{2 \mathrm{~B}}$ adenosine receptor agonist, had a negligible effect on the secretory rate: $0.59 \pm 0.08 \mu \mathrm{L} / \mathrm{min}$ in the control and $0.63 \pm 0.06 \mu \mathrm{L} / \mathrm{min}$ with BAY $60-6583$ (Figure $6 \mathrm{D}$; $P$ $=0.72, n=5$ rats). However, the protein concentration showed a tendency to decrease from $102.9 \pm 14.8$ to $65.5 \pm 5.9 \mathrm{~g} / \mathrm{L}$ (Figure $6 \mathrm{E} ; \mathrm{P}=0.07$ ), indicating ductal secretion. The $\mathrm{HCO}_{3}{ }^{-}$concentration was slightly increased from $31.3 \pm 3.4$ to $38.3 \pm 2.4 \mathrm{mM}$ (Figure $6 \mathrm{~F} ; P=0.30$ ). In the control experiment, secretin (Sec, $0.1 \mathrm{nmol} / \mathrm{kg}$ body weight) significantly increased the secretory rate and $\mathrm{HCO}_{3}{ }^{-}$concentration in pancreatic juice, indicating that ducts secreted an $\mathrm{HCO}_{3}{ }^{-}$-rich fluid, as reported previously [20] (Figure $6 \mathrm{~A}, \mathrm{C}$ ). In addition, cholecystokinin (CCK, $0.3 \mathrm{nmol} / \mathrm{kg}$ body weight) increased the secretory rate and protein concentration, but decreased the $\mathrm{HCO}_{3}{ }^{-}$concentration, indicating that acini secreted digestive enzyme- and $\mathrm{Cl}^{-}$-rich neutral fluid [21] (Figure 6A-C). The vehicle control (0.4\% DMSO in saline) did not influence exocrine secretion for $40 \mathrm{~min}$ (Figure 6G-I; $n=3$ rats).

\subsection{Effect of Adenosine Receptor Antagonists on Pancreatic Secretion in Rats}

Cholecystokinin stimulates the release of ATP and ectonucleosides from acini into pancreatic juice [7]. Adenosine is produced by the hydrolysis of ATP in the ductal lumen. In order to demonstrate whether luminal adenosine regulated adenosine receptors, specific antagonists were used. The moderate concentration of cholecystokinin (CCK, $0.1 \mathrm{nmol} / \mathrm{kg}$ body weight) increased the secretory rate and protein concentration, as reported previously [21] (Figure 7A,B; $n=4$ rats). The response to CCK was reproducible based on repeated applications in the vehicle control experiments. In preliminary experiments, the intravenous injection of 2-(2-Furanyl)-7-[3-(4-methoxyphenyl)propyl]-7H-pyrazolo $[4,3-e][1,2,4]$ triazolo[1,5-c]pyrimidin-5-amine (SCH-442416; $10 \mathrm{nmol} / \mathrm{kg}$ body weight), an $\mathrm{A}_{2 \mathrm{~A}}$ adenosine receptor antagonist, slightly decreased the secretory rate to $74.2 \pm 0.2 \%$ of the first stimulation (Figure 7D; $P=0.36, n=2$ rats). Additionally, the intravenous injection of 8-[4-[4-(4-chlorophenzyl)piperazide-1-sulfonyl)phenyl]]-1-propylxanthine (PSB 603; $10 \mathrm{nmol} / \mathrm{kg}$ body weight), an $\mathrm{A}_{2 \mathrm{~B}}$ adenosine receptor antagonist, slightly decreased the secretory rate to $76.4 \pm 7.1 \%$ (Figure 7G; $P=0.31, n=5$ rats). Neither SCH-442416 nor PSB 603 led to an increase in the concentration of protein (Figure 7E,H) or had a significant effect on the $\mathrm{HCO}_{3}{ }^{-}$concentration (Figure $7 \mathrm{C}, \mathrm{F}, \mathrm{I}$ ). 

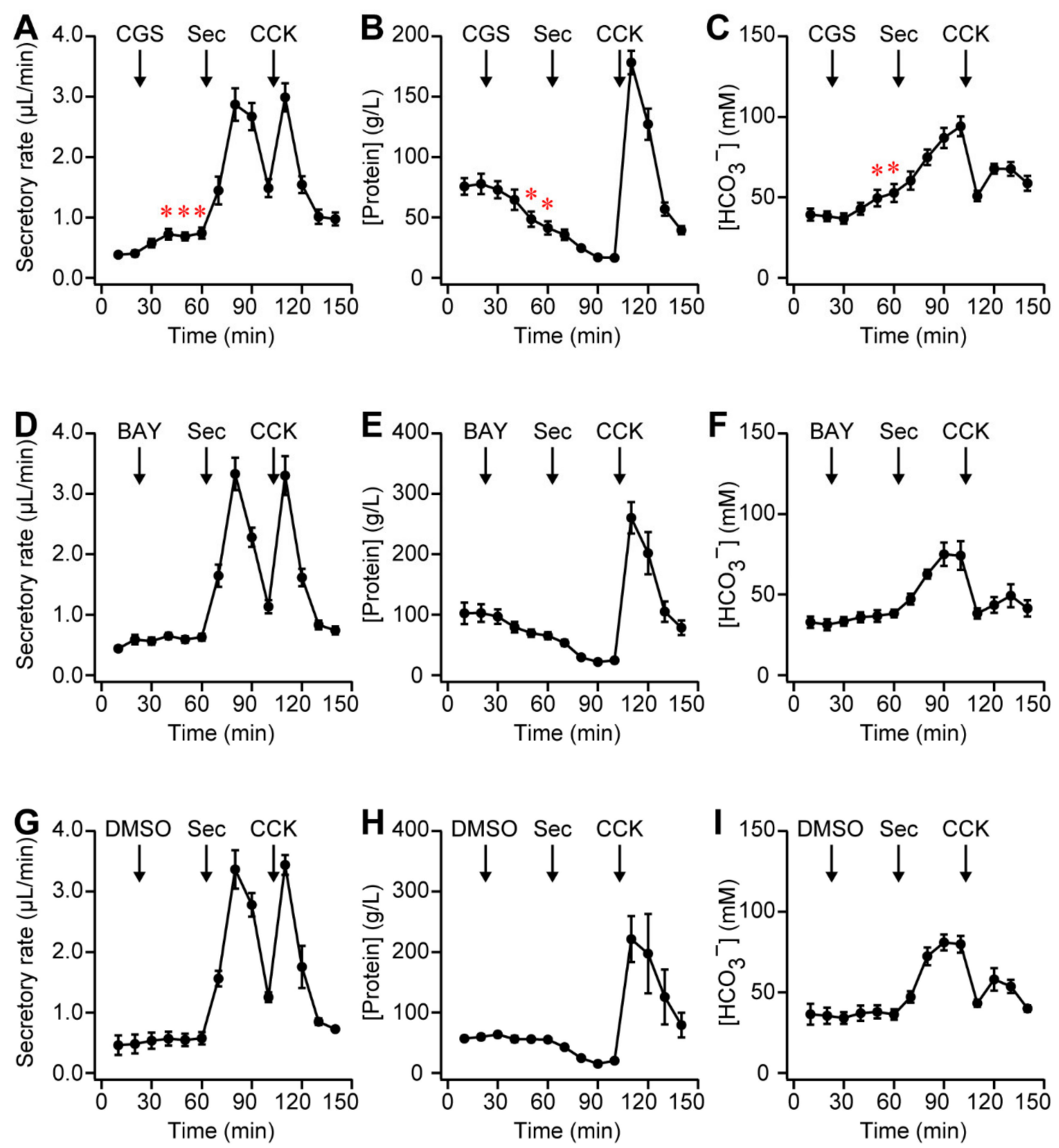

Figure 6. (A) Time-course of secretory rate of pancreatic juice from the anesthetized rats, which were intravenously injected with 4-[2-[[6-Amino-9-( $N$-ethyl- $\beta$-D-ribofuranuronamidosyl)-9H-purin-2-yl]amino] ethyl]benzenepropanoic acid (CGS 21680; CGS, $20 \mathrm{nmol} / \mathrm{kg}$ body weight), secretin (Sec, $0.1 \mathrm{nmol} / \mathrm{kg}$ body weight), and cholecystokinin (CCK, $0.3 \mathrm{nmol} / \mathrm{kg}$ body weight), as indicated by arrows ( $n=6$ rats, $* p<0.05$ ). Values were compared with the control value at $20 \mathrm{~min}$. Pancreatic juice was collected in a silicone tube. Sample volumes were determined by the length of pancreatic juice in the silicone tube. The concentrations of protein (B) and $\mathrm{HCO}_{3}{ }^{-}$(C) in pancreatic juice. (D-F) Time-courses of experiments in the anesthetized rats, which were intravenously injected with 2-(\{6-Amino-3,5-dicyano-4-[4-(cyclopropylmethoxy)phenyl]pyridin-2-yl\}sulfanyl)acetamide (BAY 60-6583; BAY, $20 \mathrm{nmol} / \mathrm{kg}$ body weight), secretin, and cholecystokinin ( $n=5 \mathrm{rats})$. (G-I) Time-courses of experiments in the anesthetized rats, which were intravenously injected with vehicle control (0.4\% DMSO in saline, 1 $\mathrm{mL} / \mathrm{kg}$ body weight), secretin, and cholecystokinin ( $n=3$ rats). Secretin increased the secretory rate (A,D) and $\mathrm{HCO}_{3}{ }^{-}$concentration in pancreatic juice $(\mathbf{C}, \mathbf{F})$, indicating ductal secretion. Cholecystokinin increased the secretory rate and protein concentration $(\mathbf{B}, \mathbf{E})$, indicating acinar secretion. 

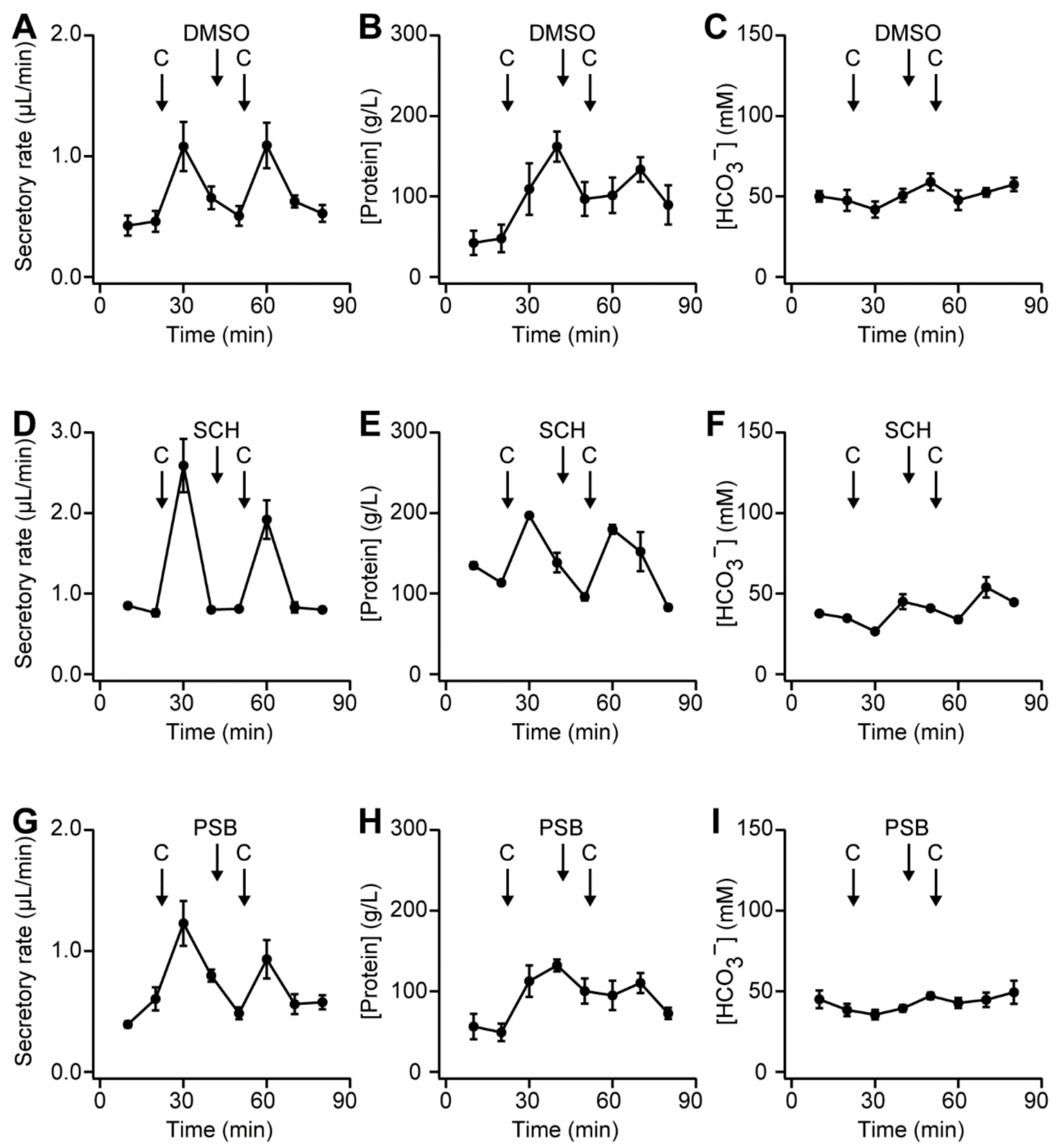

Figure 7. (A) Time-course of secretory rate of pancreatic juice from the anesthetized rats, which were intravenously injected with cholecystokinin (CCK, $0.1 \mathrm{nmol} / \mathrm{kg}$ body weight) and vehicle control ( $0.1 \%$ DMSO in saline, $1 \mathrm{~mL} / \mathrm{kg}$ body weight), indicated by arrows ( $n=4$ rats). The concentrations of protein (B) and $\mathrm{HCO}_{3}^{-}$(C) in pancreatic juice. (D-F) Time-courses of experiments in the anesthetized rats, which were intravenously injected with cholecystokinin and 2-(2-Furanyl)-7-[3-(4-methoxyphenyl)propyl]-7H-pyrazolo[4,3-e][1,2,4]triazolo[1,5-c]pyrimidin-5-amine (SCH-442416; SCH, $10 \mathrm{nmol} / \mathrm{kg}$ body weight) ( $n=2$ rats). (G-I) Time-courses of experiments in the anesthetized rats, which were intravenously injected with cholecystokinin and 8-[4-[4-(4-chlorophenzyl)piperazide-1-sulfonyl)phenyl]]-1-propylxanthine (PSB 603; PSB, 10 $\mathrm{nmol} / \mathrm{kg}$ body weight) ( $n=5$ rats). Neither SCH-442416 nor PSB 603 increased the concentrations of protein $(\mathbf{E}, \mathbf{H})$, and both had a negligible effect on the $\mathrm{HCO}_{3}{ }^{-}$concentration $(\mathbf{F}, \mathbf{I})$.

\subsection{Expression of ADORA2B Associated with Poor Prognosis of Pancreatic Adenocarcinoma}

In contrast to the rat pancreas, the $\mathrm{A}_{2 \mathrm{~B}}$ adenosine receptors showed the highest mRNA levels among four subtypes in human pancreatic adenocarcinoma cell lines [8]. To determine whether the expression of adenosine receptors was associated with a poor prognosis of pancreatic adenocarcinoma patients, 
we conducted statistical analysis using The Cancer Genome Atlas (TCGA) database. Analysis of RNA-sequencing data of pancreatic adenocarcinoma (TCGA, Provisional) revealed that a low expression of $A D O R A 2 A$, which encodes the $\mathrm{A}_{2 \mathrm{~A}}$ adenosine receptor, was associated with poor overall survival and disease-free survival (Figure $8 \mathrm{~A}, \mathrm{~B} ; \log$-rank $P=0.0302$ and $P=0.0104$, respectively). In contrast, high expression of $A D O R A 2 B\left(\mathrm{~A}_{2 \mathrm{~B}}\right.$ adenosine receptor) was associated with poor disease-free survival (Figure $8 \mathrm{D} ; \log$-rank $P=0.0125$ ). However, the expression of ADORA1 and ADORA3 was not associated with the prognosis of pancreatic adenocarcinoma patients (log-rank $P=0.310$ and $P=0.322$, respectively).
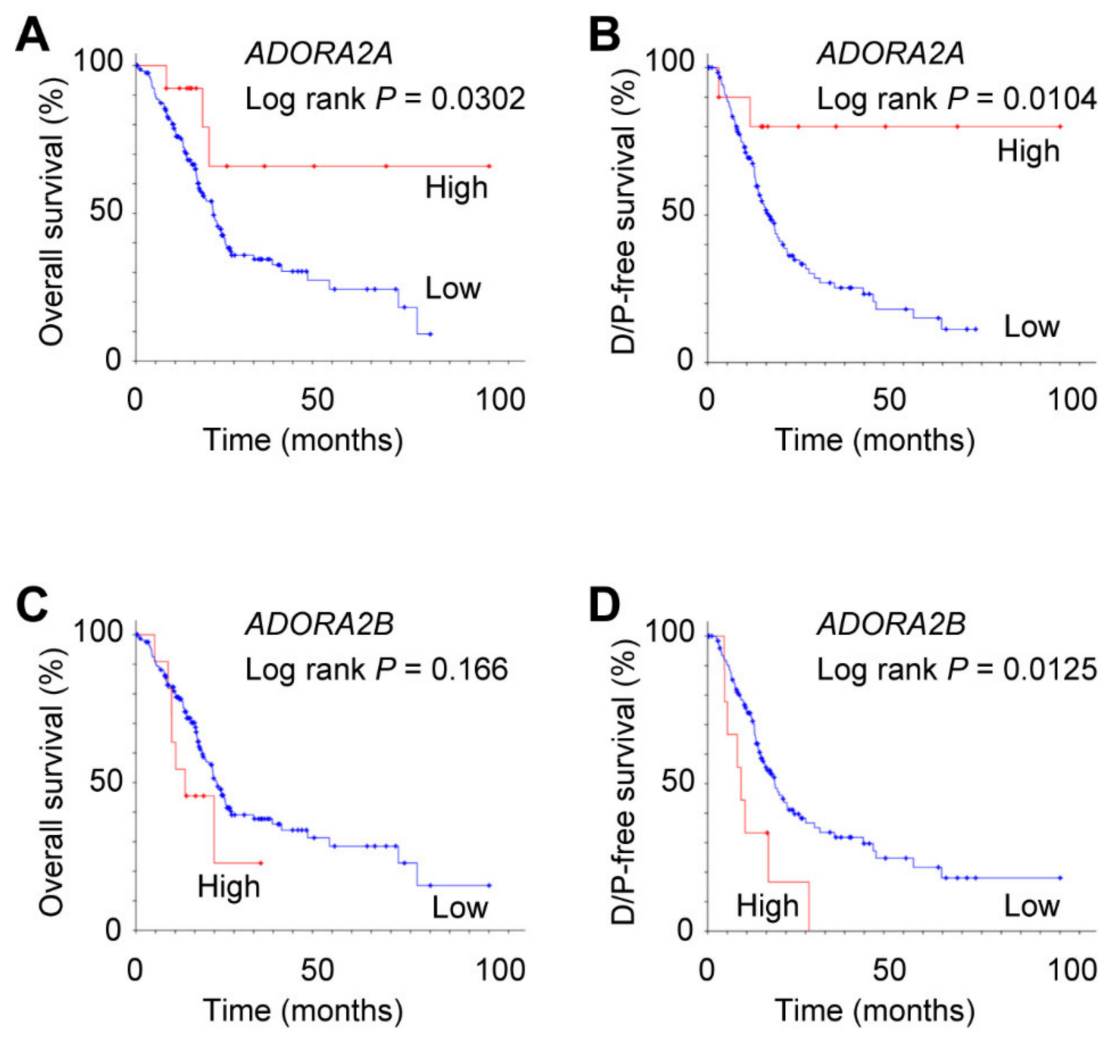

Figure 8. Association of mRNA expression of $A D O R A 2 A$ and $A D O R A 2 B$ with overall survival $(\mathbf{A}, \mathbf{C})$ and disease/progression (D/P)-free survival (B,D) in pancreatic adenocarcinoma patients. (A) High $(n=13)$ and low $(n=165)$ expression of $A D O R A 2 A(P=0.0302)$. $(\mathbf{B})$ High $(n=10)$ and low $(n=128)$ expression of $A D O R A 2 A(P=0.0104)$. (C) Median survival time was 12.5 and 20.6 months with high $(n=12)$ and low $(n=166)$ expression of $A D O R A 2 B$, respectively $(P=0.166)$. (D) Median disease-free survival time was 8.5 and 17.1 months with high $(n=10)$ and low $(n=128)$ expression of $A D O R A 2 B$, respectively $(P=0.0125)$.

\section{Discussion}

In the present study, it was demonstrated that the $\mathrm{A}_{2 \mathrm{~A}}$ adenosine receptor contributed to exocrine secretion in the rodent pancreas. This conclusion was based on the following major results: the $\mathrm{A}_{2 \mathrm{~A}}$ adenosine receptor agonist stimulated a $\mathrm{HCO}_{3}{ }^{-}$-rich fluid secretion from the rat pancreas (Figure $6 \mathrm{~A}-\mathrm{C}$ ); the $\mathrm{A}_{2 \mathrm{~A}}$ adenosine receptor colocalized with ezrin in the luminal membrane of duct cells in the mouse and guinea pig pancreas (Figures 3 and 4), as reported in rats previously. The conclusion is consistent with a pharmacological study in the dog pancreas [10].

\subsection{Compartmentalization of cAMP Signaling in the Luminal Regions of Pancreatic Duct Cells}

In pancreatic ducts, adenosine is produced by the hydrolysis of ATP that is secreted from acini by CCK stimulation [6]. Adenosine binds to adenosine receptors on the luminal membrane 
of duct cells and stimulates ductal secretion [22]. In the present study, $A_{2 A}$ and $A_{2 B}$ adenosine receptor antagonists showed a tendency to suppress $25 \%$ of the secretory rate by CCK stimulation (Figure 7), indicating acini-to-duct signaling. $A_{2 A}$ and $A_{2 B}$ adenosine receptors primarily signal via $G_{S}$ proteins, resulting in the activation of adenylyl cyclase, an increase in cAMP production, activation of a membrane-associated isoform of protein kinase A (type II PKA), and subsequent activation of cAMP-activated $\mathrm{Cl}^{-}$channels (CFTR) [23-25]. Previous studies reported that ezrin forms the scaffold for type II PKA and cAMP signaling compartments, including the $\mathrm{A}_{2 \mathrm{~B}}$ adenosine receptor, adenylyl cyclase, and CFTR [26-28]. The membrane-associated adenylyl cyclase isoforms (AC3, AC4, AC6, AC7, and AC9) were found to be expressed in the mouse pancreas [29]. Furthermore, AC6 was shown to play a critical role in cAMP/PKA-mediated signaling in pancreatic exocrine cells. The AC6 physically and functionally associates with CFTR at the apical surface of intestinal epithelial cells [30]. A recent study reported that the stimulation of $A_{2 A}$ adenosine receptors activates AC6, which is bound to A-kinase-anchoring protein (AKAP79/150), to synthesize cAMP that is used by PKA and phosphodiesterase 3A (PDE3A) in hepatocytes [31]. Further studies are required to clarify whether $\mathrm{A}_{2 \mathrm{~A}}$ adenosine receptors associate with $\mathrm{AC} 6$ and lead to the compartmentalization of cAMP signaling in the luminal regions of pancreatic duct cells.

\subsection{Role of $A_{2 A}$ and $A_{2 B}$ Adenosine Receptors in Pancreas}

In accordance with the present results, previous studies demonstrated that $A_{2 A}$ adenosine receptors regulated anion secretion in the gerbil middle ear epithelium [32], rabbit distal bright convoluted tubule cell line [33], and mouse colonic epithelia [34]. In addition to epithelial transport, the $\mathrm{A}_{2 \mathrm{~A}}$ adenosine receptor is known to be involved in the endocrine pancreas [13]. In the present study, $A_{2 A}$ and $A_{2 B}$ adenosine receptors were detected in insulin-positive $\beta$ cells (Figures 1 and 2). A previous study demonstrated that $\mathrm{A}_{2 \mathrm{~A}}$ adenosine receptors stimulated insulin secretion on mouse islets [14]. However, the $A_{2 B}$ adenosine receptor antagonists were shown to increase plasma insulin levels in rats [35]. Future studies are required to clarify the intracellular signaling in pancreatic $\beta$ cells.

\subsection{Composition of Adenosine Receptor Subtype in Duct Cells}

Several limitations of this study should be acknowledged. The protein level of $A_{2 A}$ and $A_{2 B}$ adenosine receptors could not be quantified by immunohistochemical analysis. The effects of CGS 21680 and BAY 60-6583 were small compared to those of secretin in in vivo experiments (Figure 6). Only the maximum dose of the chemical was tested. In the present study, ductal secretion was stimulated significantly more by CGS 21680 than BAY 60-6583 at the same concentration, indicating that $\mathrm{A}_{2 \mathrm{~A}}$ adenosine receptors were dominant in rat duct cells, whereas $\mathrm{BAY}$ 60-6583 showed a tendency to promote $\mathrm{HCO}_{3}{ }^{-}$-rich fluid secretion (Figure $6 \mathrm{E}, \mathrm{F}$ ). Thus, we cannot rule out the existence of $\mathrm{A}_{2 \mathrm{~B}}$ adenosine receptors in pancreatic duct cells. Previous studies postulated that $A_{2 A}$ and $A_{2 B}$ adenosine receptors form functional heterooligomers [36]. The affinities of the $A_{2 A}$ adenosine receptors for adenosine or CGS 21680 were shown to be decreased on co-expression with $A_{2 B}$ adenosine receptors in recombinant cells [37]. Meanwhile, the affinity of $A_{2 B}$ adenosine receptors for BAY 60-6583 was not altered by co-expression with $\mathrm{A}_{2 \mathrm{~A}}$ adenosine receptors. Future studies are needed in order to establish the presence of the heterooligomer in pancreatic duct cells and its functional relevance.

\subsection{A Potential Therapeutic Target for Pancreatic Cancer}

In contrast to the present results, we demonstrated that adenosine regulated anion secretion via $\mathrm{A}_{2 \mathrm{~B}}$ adenosine receptors in the luminal membrane of Capan-1, which is a human pancreas adenocarcinoma cell line [9]. The $A_{2 B}$ adenosine receptors had the highest mRNA level among four subtypes in human pancreatic adenocarcinoma cell lines (PANC-1 and CFPAC-1) [8]. In silico analysis of TCGA data showed that a high mRNA expression of $A D O R A 2 B$ was associated with a poor disease-free survival of pancreatic adenocarcinoma patients (Figure $8 \mathrm{D}$ ). However, a low expression of ADORA2A was associated with poor prognosis (Figure $8 \mathrm{~A}, \mathrm{~B}$ ). Similarly, the expression of $\mathrm{A}_{2 \mathrm{~B}}$ adenosine receptors 
was highest in prostate cancer cells and bladder urothelial carcinoma [38,39]. Moreover, mRNA and the protein expression of $\mathrm{A}_{2 \mathrm{~B}}$ adenosine receptors were consistently upregulated in bladder urothelial and colorectal carcinoma compared with normal tissues [39,40]. The high expression of $A_{2 B}$ adenosine receptors was associated with a poor prognosis in bladder urothelial carcinoma and breast cancer patients $[39,41]$. The expression of $\mathrm{A}_{2 \mathrm{~B}}$ adenosine receptors was increased in colon and breast cancer cells by hypoxia, suggesting a potential therapeutic target for cancer $[40,42]$. Indeed, selective $\mathrm{A}_{2 \mathrm{~B}}$ adenosine receptor antagonists inhibited the proliferation of prostate, colon, and breast cancer cells $[38,40,43]$. The blockade of $A_{2 B}$ adenosine receptors was shown to increase the sensitivity of mouse GL261 glioma cells to the chemotherapeutic drug temozolomide [44]. In addition, the selective antagonist improved the survival of mice bearing metastatic breast tumors [41]. Future studies are needed in order to verify the presence of $\mathrm{A}_{2 \mathrm{~B}}$ adenosine receptors in primary pancreatic tumors and confirm their pathophysiological functions related to proliferation, metastasis, and chemoresistance in pancreatic cancer.

\section{Materials and Methods}

\subsection{Experimental Animals}

Male Sprague-Dawley rats [specific pathogen free (SPF), 12-14 weeks old, 320-430 g], male Jcl:ICR mice (SPF, 8 weeks old, 36-38 g), and female Hartley guinea pigs (SPF, 4-8 weeks old, 300-420 g) were housed in the animal care facility of the Laboratory Animal Center, Kansai Medical University, Japan, under a 12-h light-dark cycle (lights on at 8:00). Constant temperature $\left(21-23^{\circ} \mathrm{C}\right)$ and relative humidity $(40-60 \%)$ were maintained. The animals had free access to standard diet and water. The care of the animals and experimental procedures were approved by the Animal Experimentation Committee of Kansai Medical University (approval numbers 13-027 of 14 February 2013, 14-010 of 27 February 2014, and 15-106 of 25 May 2015). Every effort was made to reduce the number of the animals used and minimize animal suffering.

\subsection{Preparation of Paraffin-Embedded Sections}

The rats were anesthetized with isoflurane and a mixture of medetomidine $[0.375 \mathrm{mg} / \mathrm{kg}$ body weight (b.w.) intraperitoneal (i.p.)], midazolam ( $2.0 \mathrm{mg} / \mathrm{kg}$ b.w.), and butorphanol ( $2.5 \mathrm{mg} / \mathrm{kg} \mathrm{b.w.).}$ The mice were anesthetized with isoflurane and a mixture of medetomidine $(0.3 \mathrm{mg} / \mathrm{kg}$ body weight i.p.), midazolam ( $4.0 \mathrm{mg} / \mathrm{kg} \mathrm{b.w.),} \mathrm{and} \mathrm{butorphanol} \mathrm{(} 5.0 \mathrm{mg} / \mathrm{kg}$ b.w.). The guinea pigs were anesthetized with isoflurane and a mixture of medetomidine $(0.5 \mathrm{mg} / \mathrm{kg}$ body weight i.p.), midazolam $(5.0 \mathrm{mg} / \mathrm{kg}$ b.w.), and butorphanol ( $2.5 \mathrm{mg} / \mathrm{kg} \mathrm{b.w.).} \mathrm{The} \mathrm{anesthetized} \mathrm{animals} \mathrm{were} \mathrm{perfused} \mathrm{transcardially}$ with $4 \%$ paraformaldehyde in phosphate-buffered saline (PBS). The pancreas was fixed with $4 \%$ paraformaldehyde in PBS for $24 \mathrm{~h}$, embedded in paraffin, and sectioned.

\subsection{Immunohistochemistry}

Detailed methods of immunohistochemistry were previously described [9]. Briefly, autofluorescence was blocked by $0.1 \mathrm{M}$ Tris-glycine. Non-specific binding was blocked with $2 \%$ normal serum in PBS. Preparations were subsequently incubated with primary antibodies for $\mathrm{A}_{2 \mathrm{~A}}$ and $\mathrm{A}_{2 \mathrm{~B}}$ adenosine receptors (ADORA2A and ADORA2B), glucagon, insulin, ezrin, and PECAM-1 (platelet endothelial cell adhesion molecule-1) in immunoreaction enhancer solution (Can Get Signal immunostain; Toyobo, Osaka, Japan) overnight at $4{ }^{\circ} \mathrm{C}$ (Table 1). Secondary antibodies conjugated to Alexa488, Alexa568, or Alexa647 (1:400; Molecular Probes) were added for $1 \mathrm{~h}$. As the isotype control, normal rabbit IgG ( $2 \mu \mathrm{g} / \mathrm{mL}$; Wako Pure Chemical, Osaka, Japan) was used, and scanning was performed using the same settings. Nuclei were stained with $4^{\prime}, 6$-diamidino-2-phenylindole (DAPI) at $1 \mu \mathrm{g} / \mathrm{mL}$. Fluorescence was observed with a confocal laser scanning microscope (LSM510 META; Carl Zeiss, Oberkochen, Germany). 
Table 1. Antibodies used in immunohistochemistry.

\begin{tabular}{|c|c|c|c|c|c|c|}
\hline \multirow{2}{*}{ Protein Accession } & \multirow{2}{*}{ Antigen } & \multicolumn{3}{|c|}{ Correlation } & \multirow{2}{*}{ Dilution } & \multirow{2}{*}{$\begin{array}{c}\text { Catalogue Number } \\
\text { Manufacturer }\end{array}$} \\
\hline & & Rat & Mouse & Guinea Pig & & \\
\hline $\begin{array}{l}\text { ADORA2A } \\
\text { NP_000666 }\end{array}$ & $331-412$ & $57 \%$ & $62 \%$ & $78 \%$ & $1: 100$ & $\begin{array}{c}\text { sc-13937 } \\
\text { Santa Cruz }\end{array}$ \\
\hline $\begin{array}{l}\text { ADORA2B } \\
\text { NP_000667 }\end{array}$ & $147-166$ & $70 \%$ & $65 \%$ & $85 \%$ & $1: 800$ & $\begin{array}{c}\text { AAR-003 } \\
\text { Alomone Labs }\end{array}$ \\
\hline $\begin{array}{l}\text { Glucagon } \\
\text { NP_999489 }\end{array}$ & $53-81$ & $100 \%$ & $100 \%$ & N/A & $1: 8000$ & $\begin{array}{c}\text { G2654 } \\
\text { Sigma-Aldrich }\end{array}$ \\
\hline $\begin{array}{c}\text { insulin } \\
\text { NP_000198 }\end{array}$ & recombinant & $92 \%$ & $92 \%$ & N/A & $1: 2000$ & $\begin{array}{c}\text { Y370 } \\
\text { Yanaihara Institute }\end{array}$ \\
\hline $\begin{array}{c}\text { ezrin } \\
\text { NP_001104547 }\end{array}$ & $362-585$ & $96 \%$ & $96 \%$ & $93 \%$ & $1: 200$ & $\begin{array}{c}\text { MS-661 } \\
\text { Lab Vision }\end{array}$ \\
\hline $\begin{array}{c}\text { PECAM-1 } \\
\text { NP_001027550 }\end{array}$ & C-terminus & & & & $1: 400$ & $\begin{array}{c}\text { sc-1506 } \\
\text { Santa Cruz }\end{array}$ \\
\hline
\end{tabular}

\subsection{Western Immunoblotting}

Male Sprague-Dawley rats were sacrificed by cervical dislocation. Pancreatic ducts were isolated by enzymatic digestion and microdissection from the pancreas, as previously described [1]. The pancreas was removed and digested with collagenase (Type IV, $124 \mathrm{U} / \mathrm{mL}$; Worthington Biochemical, Lakewood, NJ, USA) and trypsin inhibitor (0.01\%; Sigma, St. Louis, MO, USA) in Tyrode solution at $37^{\circ} \mathrm{C}$ for $1 \mathrm{~h}$ with vigorous shaking. Tyrode solution contained the following (in $\mathrm{mM}$ ): $140 \mathrm{NaCl}, 0.33 \mathrm{NaH}_{2} \mathrm{PO}_{4}, 5.4 \mathrm{KCl}, 1.8$ $\mathrm{CaCl}_{2}, 0.5 \mathrm{MgCl}_{2}, 5$ 4-(2-hydroxyethyl)-1-piperazineethanesulfonic acid (HEPES), and 5.5 D-glucose; $\mathrm{pH}$ was adjusted to 7.4 with $\mathrm{NaOH}$. Interlobular and intralobular ducts (outside diameter of 20-60 $\mu \mathrm{m}$ ) were microdissected under a stereomicroscope (M205 C; Leica Microsystems, Wetzlar, Germany).

The ducts were washed with cold PBS, treated with trichloroacetic acid $(10 \%)$ on ice for $30 \mathrm{~min}$, and then centrifuged. The pellet was solubilized in lysis buffer containing urea (9 M), Triton X-100 $(2 \%)$, dithiothreitol (1\%), and lithium dodecyl sulfate $(2 \%)$. The samples (30 $\mu \mathrm{g} / \mathrm{lane}$ protein) were fractionated on SDS polyacrylamide gel (7.5\%), electroblotted onto polyvinylidene fluoride (PVDF) membranes (Merck Millipore, Burlington, MA, USA), blocked with skim milk (1\%), and reacted with anti-ADORA2A (1:200) or anti-ADORA2B (1:1000) antibodies (Table 1). The reaction was visualized with a secondary antibody labeled with alkaline phosphatase (Promega, Madison, WI, USA).

Capan-1 cells (\#HTB-79; ATCC) were grown in Iscove's modified Dulbecco's medium with Glutamax (Gibco; Invitrogen, Carlsbad, CA, USA) and 20\% fetal bovine serum (FBS) (ATCC). Cells were grown to confluent monolayers on membranes (Transwell, \#3450; Corning Inc., Corning, NY, USA). HEK293 cells (Clontech Laboratories, Mountain View, CA, USA) were cultured in Dulbecco's modified Eagle medium (Sigma). Protein samples were extracted from the cells as described above.

\subsection{In Vivo Collection of Pancreatic Secretion}

Male Sprague-Dawley rats were left overnight without food, but with access to water. The rats were anesthetized with isoflurane, pentobarbital ( $25 \mathrm{mg} / \mathrm{kg}$ body weight i.p.), and ethyl carbamate $(1 \mathrm{~g} / \mathrm{kg} \mathrm{b.w.})$ to maintain a stable depth of anesthesia without awareness episodes. The animals were placed on a heating table to maintain body temperature. The surgical technique used to collect pancreatic juice from the rat with a slight modification is described elsewhere [20,45]. The abdomen was opened by a midline incision. The common pancreatic bile duct was cannulated, and pancreatic juice was collected in a silicone tube (CP-N 0.5 $\times 1$; Shin-Etsu Polymer, Tokyo, Japan). In order to collect pancreatic juice, free of bile, the proximal end of the bile duct was ligated and cut. For intravenous injections, a polyethylene catheter was placed in one of the external jugular veins. Sample volumes were determined by the length of pancreatic juice in the silicone tube. Samples were collected into $1 \mathrm{~mL}$ of saline, and the protein concentration was measured at OD280 with a spectrophotometer (BioPhotometer; Eppendorf, Hamburg, Germany). The samples were equilibrated with $5 \% \mathrm{CO}_{2}$ 
overnight and $\mathrm{pH}$ values were measured with a $\mathrm{pH}$ meter (B-71X; Hobiba, Kyoto, Japan) at $37^{\circ} \mathrm{C}$ in a $\mathrm{CO}_{2}$ incubator. The $\mathrm{HCO}_{3}{ }^{-}$concentration was calculated with the Henderson-Hasselbalch equation and determined with the calibration curve method.

\subsection{In Silico Analysis of TCGA Data}

Statistical analysis was performed on data from The Cancer Genome Atlas (TCGA) database using the online cBioPortal for Cancer Genomics platform (http://www.cbioportal.org) [46,47]. A total of 179 cases were selected, corresponding to mRNA data (RNA Seq V2 RSEM) from Pancreatic adenocarcinoma patients (TCGA, Provisional). A cohort of pancreatic adenocarcinoma patients was divided into those with high (Z-score $>1.5$ ) and low expressions of mRNA. Kaplan-Meier analysis with the log-rank test was performed to estimate the overall survival and disease/progression-free survival.

\subsection{Materials}

CGS 21680, BAY 60-6583, and PSB 603 were obtained from Tocris Bioscience (Bristol, UK). SCH-442416 was obtained from Sigma. Rat secretin was obtained from GenScript (Piscataway, NJ, USA). Cholecystokinin (CCK8 sulfated form) was obtained from Peptide Institute (Ibaraki, Japan).

\subsection{Statistics}

Means \pm SEM of the number $n$ of experiments are shown. Significance of the differences was analyzed by the one-way analysis of variance, with $p<0.05$ indicating significance. Data were analyzed in Igor or Microsoft Excel.

\section{Conclusions}

The results showed that $\mathrm{A}_{2 \mathrm{~A}}$ adenosine receptors may be, at least in part, involved in the exocrine secretion of pancreatic duct cells via acini-to-duct signaling. The $A_{2 A}$ and $A_{2 B}$ adenosine receptors may be a potential therapeutic target for cancer as well as exocrine dysfunctions of the pancreas.

Author Contributions: Conceptualization, M.H.; Investigation, M.H.; Original draft preparation, M.H.; Review and editing, M.H.; Funding acquisition, M.H.

Funding: This research was funded by the Pancreas Research Foundation of Japan, grant number H26-7; the Ichiro Kanehara Foundation for the Promotion of Medical Sciences and Medical Care, grant number 18KI0174; and the Osaka Community Foundation, grant number 2019IGAKU10.

Acknowledgments: The author acknowledges Hiroko Matsuda and Masahiro Ohtani for their useful discussion. The technical assistance of Yuka Yoshida is greatly acknowledged.

Conflicts of Interest: The author declares no conflict of interest. The funders had no role in the design of the study; in the collection, analyses, or interpretation of data; in the writing of the manuscript, or in the decision to publish the results.

\section{Abbreviations}

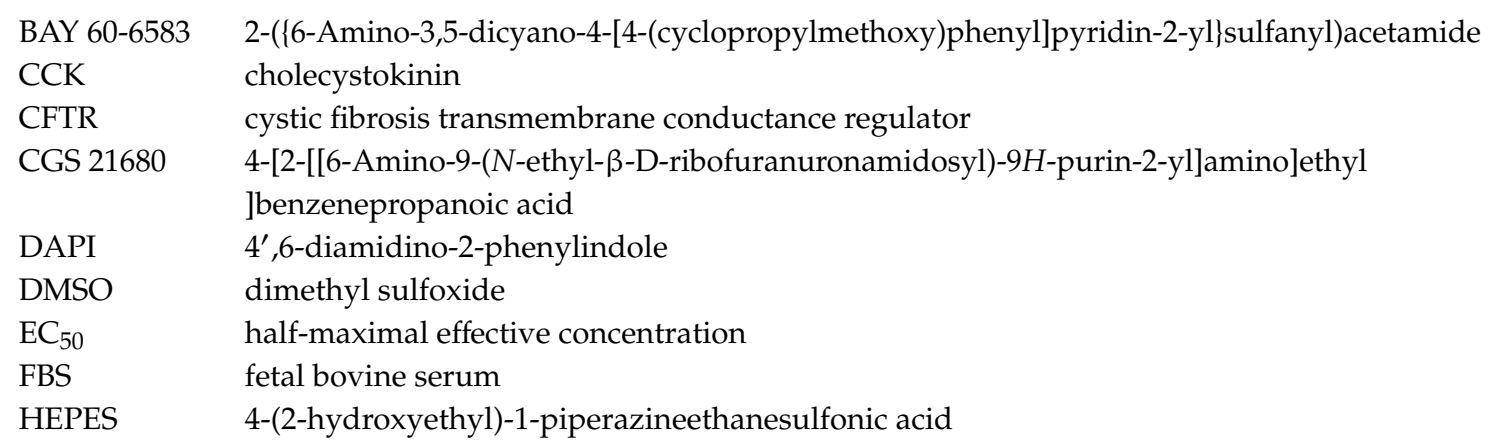




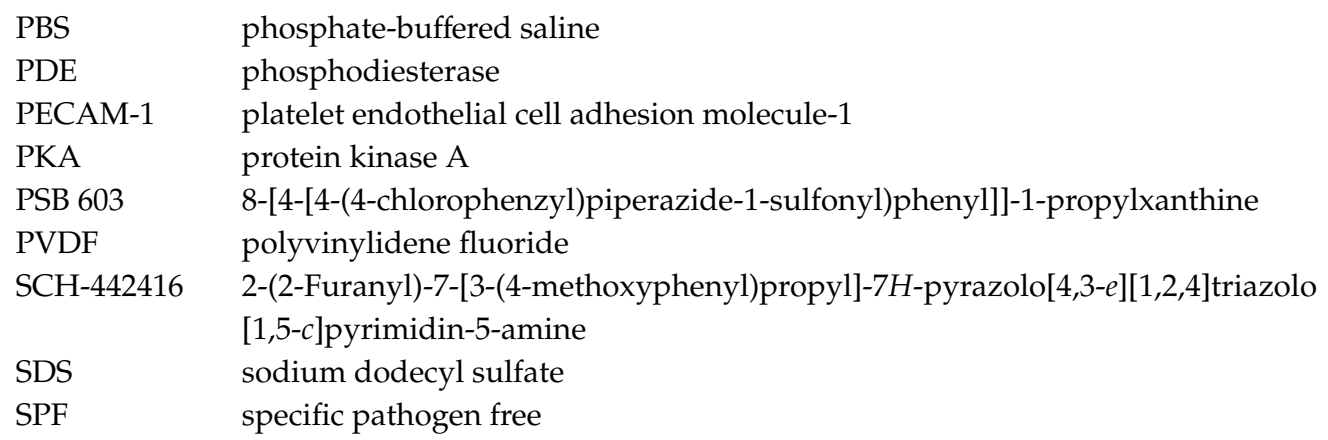

\section{References}

1. Hayashi, M.; Wang, J.; Hede, S.E.; Novak, I. An intermediate-conductance $\mathrm{Ca}^{2+}$-activated $\mathrm{K}^{+}$channel is important for secretion in pancreatic duct cells. Am. J. Physiol. Cell Physiol. 2012, 303, C151-C159. [CrossRef] [PubMed]

2. Wang, J.; Haanes, K.A.; Novak, I. Purinergic regulation of CFTR and $\mathrm{Ca}^{2+}$-activated $\mathrm{Cl}^{-}$channels and $\mathrm{K}^{+}$ channels in human pancreatic duct epithelium. Am. J. Physiol. Cell Physiol. 2013, 304, C673-C684. [CrossRef] [PubMed]

3. Wilschanski, M.; Novak, I. The cystic fibrosis of exocrine pancreas. Cold Spring Harb. Perspect. Med. 2013, 3, a009746. [CrossRef] [PubMed]

4. Andharia, N.; Hayashi, M.; Matsuda, H. Electrophysiological properties of anion exchangers in the luminal membrane of guinea pig pancreatic duct cells. Pflügers Arch. 2018, 470, 897-907. [CrossRef] [PubMed]

5. Sakata, N.; Yoshimatsu, G.; Kodama, S. Development and Characteristics of Pancreatic Epsilon Cells. Int. J. Mol. Sci. 2019, 20, 1867. [CrossRef] [PubMed]

6. Burnstock, G.; Novak, I. Purinergic signalling in the pancreas in health and disease. J. Endocrinol. 2012, 213, 123-141. [CrossRef]

7. Yegutkin, G.G.; Samburski, S.S.; Jalkanen, S.; Novak, I. ATP-consuming and ATP-generating enzymes secreted by pancreas. J. Biol. Chem. 2006, 281, 29441-29447. [CrossRef]

8. Novak, I.; Hede, S.E.; Hansen, M.R. Adenosine receptors in rat and human pancreatic ducts stimulate chloride transport. Pflügers Arch. 2008, 456, 437-447. [CrossRef]

9. Hayashi, M.; Inagaki, A.; Novak, I.; Matsuda, H. The adenosine $\mathrm{A}_{2 \mathrm{~B}}$ receptor is involved in anion secretion in human pancreatic duct Capan-1 epithelial cells. Pflügers Arch. 2016, 468, 1171-1181. [CrossRef]

10. Iwatsuki, K. Subtypes of adenosine receptors on pancreatic exocrine secretion in anaesthetized dogs. Fundam. Clin. Pharmacol. 2000, 14, 203-208. [CrossRef]

11. Hillaire-Buys, D.; Bertrand, G.; Gross, R.; Loubatières-Mariani, M.M. Evidence for an inhibitory $\mathrm{A}_{1}$ subtype adenosine receptor on pancreatic insulin-secreting cells. Eur. J. Pharmacol. 1987, 136, 109-112. [CrossRef]

12. Bertrand, G.; Petit, P.; Bozem, M.; Henquin, J.C. Membrane and intracellular effects of adenosine in mouse pancreatic $\beta$-cells. Am. J. Physiol. 1989, 257, E473-E478. [CrossRef] [PubMed]

13. Antonioli, L.; Blandizzi, C.; Csóka, B.; Pacher, P.; Haskó, G. Adenosine signalling in diabetes mellitus-pathophysiology and therapeutic considerations. Nat. Rev. Endocrinol. 2015, 11, 228-241. [CrossRef] [PubMed]

14. Ohtani, M.; Oka, T.; Ohura, K. Possible involvement of $A_{2 A}$ and $A_{3}$ receptors in modulation of insulin secretion and $\beta$-cell survival in mouse pancreatic islets. Gen. Comp. Endocrinol. 2013, 187, 86-94. [CrossRef]

15. Németh, Z.H.; Bleich, D.; Csóka, B.; Pacher, P.; Mabley, J.G.; Himer, L.; Vizi, E.S.; Deitch, E.A.; Szabó, C.; Cronstein, B.N.; et al. Adenosine receptor activation ameliorates type 1 diabetes. FASEB J. 2007, 21, 2379-2388. [CrossRef]

16. Tudurí, E.; Filiputti, E.; Carneiro, E.M.; Quesada, I. Inhibition of $\mathrm{Ca}^{2+}$ signaling and glucagon secretion in mouse pancreatic $\alpha$-cells by extracellular ATP and purinergic receptors. Am. J. Physiol. Endocrinol. Metab. 2008, 294, E952-E960. [CrossRef]

17. Yip, L.; Taylor, C.; Whiting, C.C.; Fathman, C.G. Diminished adenosine A1 receptor expression in pancreatic $\alpha$-cells may contribute to the pathology of type 1 diabetes. Diabetes 2013, 62, 4208-4219. [CrossRef] 
18. Fredholm, B.B.; Irenius, E.; Kull, B.; Schulte, G. Comparison of the potency of adenosine as an agonist at human adenosine receptors expressed in Chinese hamster ovary cells. Biochem. Pharmacol. 2001, 61, 443-448. [CrossRef]

19. Winarto, A.; Miki, T.; Seino, S.; Iwanaga, T. Morphological changes in pancreatic islets of $\mathrm{K}_{\mathrm{ATP}}$ channel-deficient mice: The involvement of $\mathrm{K}_{\mathrm{ATP}}$ channels in the survival of insulin cells and the maintenance of islet architecture. Arch. Histol. Cytol. 2001, 64, 59-67. [CrossRef]

20. Sewell, W.A.; Young, J.A. Secretion of electrolytes by the pancreas of the anaesthetized rat. J. Physiol. 1975, 252, 379-396. [CrossRef]

21. Dockray, G.J. The action of secretin, cholecystokinin-pancreozymin and caerulein on pancreatic secretion in the rat. J. Physiol. 1972, 225, 679-692. [CrossRef] [PubMed]

22. Wang, J.; Novak, I. Ion transport in human pancreatic duct epithelium, Capan-1 cells, is regulated by secretin, VIP, acetylcholine, and purinergic receptors. Pancreas 2012, 42, 452-460. [CrossRef] [PubMed]

23. Steagall, W.K.; Kelley, T.J.; Marsick, R.J.; Drumm, M.L. Type II protein kinase A regulates CFTR in airway, pancreatic, and intestinal cells. Am. J. Physiol. 1998, 274, C819-C826. [CrossRef] [PubMed]

24. Huang, P.; Trotter, K.; Boucher, R.C.; Milgram, S.L.; Stutts, M.J. PKA holoenzyme is functionally coupled to CFTR by AKAPs. Am. J. Physiol. Cell Physiol. 2000, 278, C417-C422. [CrossRef]

25. Bucheimer, R.E.; Linden, J. Purinergic regulation of epithelial transport. J. Physiol. 2004, 555, 311-321. [CrossRef]

26. Dessauer, C.W. Adenylyl cyclase-A-kinase anchoring protein complexes: The next dimension in cAMP signaling. Mol. Pharmacol. 2009, 76, 935-941. [CrossRef]

27. Li, C.; Naren, A.P. CFTR chloride channel in the apical compartments: Spatiotemporal coupling to its interacting partners. Integr. Biol. (Camb.) 2010, 2, 161-177. [CrossRef]

28. Johnstone, T.B.; Agarwal, S.R.; Harvey, R.D.; Ostrom, R.S. cAMP Signaling Compartmentation: Adenylyl Cyclases as Anchors of Dynamic Signaling Complexes. Mol. Pharmacol. 2018, 93, 270-276. [CrossRef]

29. Sabbatini, M.E.; D'Alecy, L.; Lentz, S.I.; Tang, T.; Williams, J.A. Adenylyl cyclase 6 mediates the action of cyclic AMP-dependent secretagogues in mouse pancreatic exocrine cells via protein kinase A pathway activation. J. Physiol. 2013, 591, 3693-3707. [CrossRef]

30. Thomas, A.; Ramananda, Y.; Mun, K.; Naren, A.P.; Arora, K. AC6 is the major adenylate cyclase forming a diarrheagenic protein complex with cystic fibrosis transmembrane conductance regulator in cholera. J. Biol. Chem. 2018, 293, 12949-12959. [CrossRef]

31. Guinzberg, R.; Díaz-Cruz, A.; Acosta-Trujillo, C.; Vilchis-Landeros, M.M.; Vázquez-Meza, H.; Lozano-Flores, C.; Chiquete-Felix, N.; Varela-Echavarria, A.; Uribe-Carvajal, S.; Riveros-Rosas, H.; et al. Newly synthesized cAMP is integrated at a membrane protein complex signalosome to ensure receptor response specificity. FEBS J. 2017, 284, 258-276. [CrossRef] [PubMed]

32. Furukawa, M.; Ikeda, K.; Oshima, T.; Suzuki, H.; Yamaya, M.; Sasaki, H.; Takasaka, T. A 2 adenosine receptors in Mongolian gerbil middle ear epithelium and their regulation of $\mathrm{Cl}^{-}$secretion. Acta Physiol. Scand. 1998, 163, 103-112. [CrossRef] [PubMed]

33. Rubera, I.; Tauc, M.; Verheecke-Mauze, C.; Bidet, M.; Poujeol, C.; Touret, N.; Cuiller, B.; Poujeol, P. Regulation of cAMP-dependent chloride channels in DC1 immortalized rabbit distal tubule cells in culture. Am. J. Physiol. 1999, 276, F104-F121. [CrossRef] [PubMed]

34. Lam, R.S.; Nahirney, D.; Duszyk, M. Cholesterol-dependent regulation of adenosine $\mathrm{A}_{2 \mathrm{~A}}$ receptor-mediated anion secretion in colon epithelial cells. Exp. Cell Res. 2009, 315, 3028-3035. [CrossRef]

35. Rüsing, D.; Müller, C.E.; Verspohl, E.J. The impact of adenosine and $\mathrm{A}_{2 \mathrm{~B}}$ receptors on glucose homoeostasis. J. Pharm. Pharmacol. 2006, 58, 1639-1645. [CrossRef]

36. Moriyama, K.; Sitkovsky, M.V. Adenosine A2A receptor is involved in cell surface expression of A2B receptor. J. Biol. Chem. 2010, 285, 39271-39288. [CrossRef]

37. Hinz, S.; Navarro, G.; Borroto-Escuela, D.; Seibt, B.F.; Ammon, Y.C.; de Filippo, E.; Danish, A.; Lacher, S.K.; Červinková, B.; Rafehi, M.; et al. Adenosine $\mathrm{A}_{2 \mathrm{~A}}$ receptor ligand recognition and signaling is blocked by $\mathrm{A}_{2 \mathrm{~B}}$ receptors. Oncotarget 2018, 9, 13593-13611. [CrossRef]

38. Wei, Q.; Costanzi, S.; Balasubramanian, R.; Gao, Z.G.; Jacobson, K.A. A 2 B adenosine receptor blockade inhibits growth of prostate cancer cells. Purinergic Signal. 2013, 9, 271-280. [CrossRef] 
39. Zhou, Y.; Chu, X.; Deng, F.; Tong, L.; Tong, G.; Yi, Y.; Liu, J.; Tang, J.; Tang, Y.; Xia, Y.; et al. The adenosine $\mathrm{A} 2 \mathrm{~b}$ receptor promotes tumor progression of bladder urothelial carcinoma by enhancing MAPK signaling pathway. Oncotarget 2017, 8, 48755-48768. [CrossRef]

40. Ma, D.F.; Kondo, T.; Nakazawa, T.; Niu, D.F.; Mochizuki, K.; Kawasaki, T.; Yamane, T.; Katoh, R. Hypoxia-inducible adenosine A2B receptor modulates proliferation of colon carcinoma cells. Hum. Pathol. 2010, 41, 1550-1557. [CrossRef]

41. Mittal, D.; Sinha, D.; Barkauskas, D.; Young, A.; Kalimutho, M.; Stannard, K.; Caramia, F.; Haibe-Kains, B.; Stagg, J.; Khanna, K.K.; et al. Adenosine 2B Receptor Expression on Cancer Cells Promotes Metastasis. Cancer Res. 2016, 76, 4372-4382. [CrossRef] [PubMed]

42. Lan, J.; Lu, H.; Samanta, D.; Salman, S.; Lu, Y.; Semenza, G.L. Hypoxia-inducible factor 1-dependent expression of adenosine receptor 2B promotes breast cancer stem cell enrichment. Proc. Natl. Acad. Sci. USA 2018, 115, E9640-E9648. [CrossRef] [PubMed]

43. Horigome, E.; Fujieda, M.; Handa, T.; Katayama, A.; Ito, M.; Ichihara, A.; Tanaka, D.; Gombodorj, N.; Yoshiyama, S.; Yamane, A.; et al. Mutant TP53 modulates metastasis of triple negative breast cancer through adenosine A2b receptor signaling. Oncotarget 2018, 9, 34554-34566. [CrossRef] [PubMed]

44. Yan, A.; Joachims, M.L.; Thompson, L.F.; Miller, A.D.; Canoll, P.D.; Bynoe, M.S. CD73 Promotes Glioblastoma Pathogenesis and Enhances Its Chemoresistance via $\mathrm{A}_{2 \mathrm{~B}}$ Adenosine Receptor Signaling. J. Neurosci. 2019, 39, 4387-4402. [CrossRef] [PubMed]

45. Grossman, M.I. Pancreatic secretion in the rat. Am. J. Physiol. 1958, 194, 535-539. [CrossRef] [PubMed]

46. Cerami, E.; Gao, J.; Dogrusoz, U.; Gross, B.E.; Sumer, S.O.; Aksoy, B.A.; Jacobsen, A.; Byrne, C.J.; Heuer, M.L.; Larsson, E.; et al. The cBio cancer genomics portal: An open platform for exploring multidimensional cancer genomics data. Cancer Discov. 2012, 2, 401-404. [CrossRef]

47. Gao, J.; Aksoy, B.A.; Dogrusoz, U.; Dresdner, G.; Gross, B.; Sumer, S.O.; Sun, Y.; Jacobsen, A.; Sinha, R.; Larsson, E.; et al. Integrative analysis of complex cancer genomics and clinical profiles using the cBioPortal. Sci. Signal. 2013, 6, pl1. [CrossRef]

(C) 2019 by the author. Licensee MDPI, Basel, Switzerland. This article is an open access article distributed under the terms and conditions of the Creative Commons Attribution (CC BY) license (http://creativecommons.org/licenses/by/4.0/). 